\title{
Copper, Zinc and Manganese Determination in Saline Samples Employing FAAS After Separation and Preconcentration on Amberlite XAD-7 and Dowex 1X-8 Loaded with Alizarin Red S
}

\author{
Maria das Graças A. Korn ${ }^{*, a}$, Aníbal de Freitas Santos Jr. ${ }^{b}$, Helena V. Jaeger ${ }^{a}$, \\ Nívia Maria S. Silva a and Antônio C. Spínola Costa ${ }^{a}$ \\ ${ }^{a}$ Instituto de Química, Universidade Federal da Bahia, Campus Universitário da Federação, 40170-290 \\ Salvador - BA, Brazil \\ ${ }^{b}$ Departamento de Saúde, Colegiado de Ciências Farmacêuticas, Universidade Estadual de Feira de Santana, \\ Campus Universitário s/n, 44031-460 Feira de Santana - BA, Brazil
}

\begin{abstract}
Dois procedimentos foram comparados para separação e pré-concentração de traços de cobre, zinco e manganês em amostras salinas. Os métodos basearam-se na adsorção dos íons metálicos sobre duas fases sólidas obtidas por impregnação de uma resina não-iônica Amberlite XAD-7 e uma resina aniônica Dowex 1X8-50 com o reagente vermelho de alizarina $S$ (ARS), ácido nítrico foi utilizado para re-extrair os cátions das fases sólidas, os quais foram determinados por FAAS. Para o sistema Amberlite XAD-7/ARS, Mn, Cu e Zn foram quantitativamente retidos, na faixa de $\mathrm{pH}$ de 8,5 a 10,0, para uma massa de $0,50 \mathrm{~g}$ da fase sólida, após 5 min de agitação e uma massa total de até $200 \mu \mathrm{g}$ de cada metal. Os elementos foram eluídos com $5 \mathrm{~mL}$ de $\mathrm{HNO}_{3} 3 \mathrm{~mol} \mathrm{~L}^{-1}$, com recuperação $\geq 95 \%$, obtendo-se fator de pré-concentração de até 50 vezes para $\mathrm{Zn}$ e de 10 vezes para $\mathrm{Mn}$ e $\mathrm{Cu}$. Para o sistema Dowex 1X8-50/ARS, $\mathrm{Cu}, \mathrm{Mn}$ e $\mathrm{Zn}$ foram quantitativamente retidos, na faixa de $\mathrm{pH}$ de 8,1 a 9,0 e Zn em pH 8,1, usando uma massa de 0,75 g da fase sólida, após 90 min de agitação e uma massa total de até $50 \mu \mathrm{g}$ de cada metal. Os elementos foram eluídos com $20 \mathrm{~mL}$ de $\mathrm{HNO}_{3} 2 \mathrm{~mol}$ $\mathrm{L}^{-1}$, obtendo-se fator de pré-concentração de até 5 vezes para $\mathrm{Cu}$ e $\mathrm{Zn}$. A precisão dos procedimentos foi estabelecida pela medida de 10 replicatas com $250 \mu \mathrm{g} \mathrm{L}^{-1}$ de cada íon e os desvios padrão relativos foram de $0,2 \%(\mathrm{Cu}), 0,4 \%(\mathrm{Mn})$, e $0,4 \%(\mathrm{Zn})$, para ARS-XAD7 e 0,3\% (Cu), 0,5\% (Mn), e 0,3\% (Zn), para ARS-Dowex. Os procedimentos propostos foram aplicados na determinação de $\mathrm{Mn}, \mathrm{Cu}$ e Zn em solução fisiológica e água do mar da cidade de Salvador/BA. Testes de recuperação com adição de $5 \mathrm{mg}$ dos metais às amostras revelaram eficiência no que diz respeito à exatidão e a precisão dos procedimentos propostos, com recuperação quantitativa $(\geq 95 \%)$.
\end{abstract}

Two procedures have been proposed and compared for separation and preconcentration of trace amounts of manganese, copper, and zinc in saline samples. The procedures are based in the use of Amberlite XAD-7 and an anion-exchanger Dowex 1X8-50 loaded with Alizarin Red S (ARS). In order to obtain quantitative recoveries of metal ions, various experimental parameters such as $\mathrm{pH}$, shaking time, sample volume, amounts of solid phase, effects of concomitants, capacity and cations desorptions from solid phases were optimized. For Amberlite XAD-7 impregnated with ARS (XAD 7-ARS), $\mathrm{Mn}, \mathrm{Cu}$, and $\mathrm{Zn}$ were quantitatively retained, in the $\mathrm{pH}$ range 8.5-10.0, by using $0.50 \mathrm{~g}$ of solid phase, stirring time of $5 \mathrm{~min}$ and a total mass up to $200 \mu \mathrm{g}$ of each cation. The sorbed elements were subsequently eluted with $5 \mathrm{~mL}$ of $3 \mathrm{~mol} \mathrm{~L}^{-1} \mathrm{HNO}_{3}$, with recovering over $95 \%$, and a fifty-fold preconcentration factor for $\mathrm{Zn}$ and a ten-fold preconcentration factor for $\mathrm{Mn}$ and $\mathrm{Cu}$ were obtained. For Dowex 1X8-50 impregnated with ARS (Dowex-ARS), Cu and Mn were quantitatively retained in the $\mathrm{pH}$ range 8.1 to 9.0 , and $\mathrm{Zn} \mathrm{pH} 8.1$, by using $0.75 \mathrm{~g}$ of solid phase, 90 min of stirring time and a total mass up to $50 \mu \mathrm{g}$ of each cation. The sorbed elements were subsequently eluted with $20 \mathrm{~mL}$ of $2 \mathrm{~mol} \mathrm{~L}^{-1} \mathrm{HNO}_{3}$, and a five-fold preconcentration factor to $\mathrm{Cu}$ and $\mathrm{Zn}$ was obtained. The precision of the procedure was determined by running 10 replicate samples, each one containing $250 \mu \mathrm{g} \mathrm{L}^{-1}$ of each element and the relative standard deviations were $0.2 \%(\mathrm{Cu}), 0.4 \%(\mathrm{Mn})$, and $0.4 \%(\mathrm{Zn})$, to XAD 7-ARS and $0.3 \%(\mathrm{Cu}), 0.5 \%(\mathrm{Mn})$, and $0.3 \%(\mathrm{Zn})$, to Dowex-ARS. The procedures were used for determining of $\mathrm{Mn}, \mathrm{Cu}$, and $\mathrm{Zn}$ in physiological solutions and seawater samples, from Salvador-Bahia. The analyte addition technique was used and the recoveries obtained $(\geq 95 \%)$ revealed that the proposed procedure shows good accuracy and precision.

Keywords: preconcentration, solid-liquid extraction, Amberlite XAD-7, Dowex 1X8-50, alizarin red S, saline samples

\footnotetext{
* e-mail: korn@ufba.br
} 


\section{Introduction}

The use of solutions with variable saline concentrations for man is indispensable for the industrial and physiologic activities, especially in clinical Chemistry. Solutions of $\mathrm{NaCl} 0.9 \% \mathrm{~m} / \mathrm{v}$ are used as physiologic solution, because it reflects the isotonic composition of the biologics fluids of the human body. The determination of metals in this sample is very important because contamination of sodium salts and water can complicate the conditions of the patients that use dialysis solutions. ${ }^{1}$ The determination of $\mathrm{Mn}, \mathrm{Cu}$, and $\mathrm{Zn}$ in natural waters is also important whereas these trace elements present in the matrix constitute an environmental problem and there is a lack of information on the behavior and toxic potential of these metals on the metabolism of living organisms. ${ }^{2}$ Copper is an essential element for human body, its discovery in human brain in 1921, was important to establish its functions in the body: oxygen and electrons transport, constituent of enzymes to redox reactions and involvement in the mobilization of iron to hemoglobin synthesis. ${ }^{3}$ Zinc, essential trace element for man, has been reported since $1934 .{ }^{4}$ It is associate in the insulin production, in the composition of more 90 enzymes related with acid-base catalysis, and in DNA and RNA synthesis. The manganese is associated with cartilages and bones formation..$^{5-7}$

Atomic absorption spectrometry is nowadays the most common method for trace metal determination in various materials. However the flame atomic absorption spectrometric (FAAS) determination of trace metal ions in high saline samples, such as seawater, is difficult due to various factors, particularly the low level of metal content and the high salt content of the matrix. ${ }^{8}$ Thus, trace determination in saline solutions always needs a prior separation and preconcentration steps. Several procedures extensively used for separation and preconcentration include liquidliquid extraction and solid phase extraction. However, solvent extraction suffers with problems for handling of large sample volume, mutual solubility of two phases, and emulsion formation. Consequently, in the last decade use of chelating resins for metal enrichment has increased very significantly. ${ }^{9-19}$ Their advantages include good selectivity, high preconcentration factor, easy regeneration for multiple sorption-desorption cycles and good reproducibility in the sorption characteristics.

Alizarin Red S (sodium1,2-dihydroxyanthraquinone3 -sulfonate, ARS) reacts with various metal ions to form anionic chelates, which are not extractable into organic solvents. ARS was studied for separation and preconcentration of $\mathrm{Al}, \mathrm{Cu}, \mathrm{Pb}, \mathrm{Cd}, \mathrm{Zn}$, and $\mathrm{Ni}$ in different matrices, such as alloys, biological samples and environmental samples. ${ }^{20-22}$ Therefore the potential use of ARS impregnated in resins has been scarcely explored for analytical procedures employing separation and preconcentration.

The aim of this work was to explore the possibility of the application of a chelating resins obtained by immobilization the reagent alizarin red S (ARS) on nonionic polymer sorbent Amberlite XAD-7 and anion exchanger Dowex 1X8-50 for manganese, copper, and zinc separation and preconcentration from saline samples. The sorbed elements are subsequently eluted with nitric acid and determined by FAAS. The conditions have been optimized and the methods applied for the determination of copper, zinc, and manganese in physiological solutions and seawater samples.

\section{Experimental}

\section{Reagents}

All reagents were of analytical reagent grade. Double distilled and deionized waters were used for the preparations of solutions. The laboratory glassware was kept overnight in a $10 \% \mathrm{v} / \mathrm{v}$ nitric acid solution. Before use, the glassware was washed with deionized water and dried in a dust-free environment.

Metal stock solutions were prepared from Merck standard solutions to a final concentration of $1.000 \mathrm{~g} \mathrm{~L}^{-1}$. Reference solutions were daily prepared by diluting aliquots with pure water and acidified with nitric acid. Buffer solutions were glycine/ hydrochloric acid adjusted at $\mathrm{pH} 3$, acetate buffer at $\mathrm{pH} 4$ to 6 , tris- $\mathrm{HCl}$ buffer at $\mathrm{pH} 7$ to 8 , and ammonia buffer at $\mathrm{pH} 8.5$ to 10 . Acid solutions for study of the eluents were nitric, hydrochloric and sulphuric acids (Merck) at different concentrations prepared by suitable dilution of the respective concentrated acids in deionized water. The solutions for study of concomitants effects were prepared in different percentage $(\mathrm{m} / \mathrm{v})$ of $\mathrm{Na}^{+}, \mathrm{K}^{+}, \mathrm{Ca}^{2+}, \mathrm{Mg}^{2+} \mathrm{e} \mathrm{Ba}^{2+}$, by dissolving their respective salts in the chloride, sulphates, and phosphoric forms. Solid phase was prepared with ARS (Merck), Amberlite XAD-7 (surface area, $450 \mathrm{~m}^{2} \mathrm{~g}^{-1}$; pore diameter, $450 \AA$ and bead size, 20-60 mesh) and Dowex 1X8-50 was purchased from Aldrich (Milwaukee, USA).

\section{Apparatus}

A flame atomic absorption spectrometer (Varian, Australia, model 220) employing air-acetylene flame was used for atomic absorption spectrometric measurements. The instrumental and operational parameters are showed in Table 1 and the $\mathrm{pH}$ value was measured with a PROCYON 
PHD-10 digital pH meter supplied with a combined glasscalomel electrode.

Table 1. FAAS: Instrumental and operational parameters

\begin{tabular}{lccc}
\hline Parameter & $\mathrm{Cu}$ & $\mathrm{Zn}$ & $\mathrm{Mn}$ \\
\hline Wavelength $(\mathrm{nm})$ & 324.8 & 213.9 & 279.5 \\
Current lamps $(\mathrm{mA})$ & 4 & 5 & 5 \\
Spectral resolution $(\mathrm{nm})$ & 0.5 & 1.0 & 0.2 \\
Reference solutions $\left(\mu \mathrm{g} \mathrm{mL}^{-1}\right)$ & $0-1.2$ & $0-1.0$ & $0-1.2$ \\
\hline
\end{tabular}

Preparation and characterization of chelating resins

Amberlite XAD-7 and Dowex 1X8-50 were treated with an ethanol-HCl-water (2:1:1) solution overnight. Later on the resin was rinsed with deionized water until $\mathrm{pH}$ neutral and kept in desiccator with silica gel for $24 \mathrm{~h}$. After dried, $10.0 \mathrm{~g}$ of Amberlite XAD-7 were weighed with $0.50 \mathrm{~g}$ of ARS and transferred to an Erlenmeyer containing $250 \mathrm{~mL}$ of deionized water. This mixture was stirred for $3 \mathrm{~h}$ with a magnetic stirrer, vacuum filtered using a Buckner funnel and filter paper (Framex, fast filtration, $0.00007 \%$ ash) and kept in desiccators with silica gel for $24 \mathrm{~h}$. The DowexARS solid phase was similarly prepared. Chelating resins were characterized by IR spectra.

Recommended procedure for separation and preconcentration - XAD 7-ARS resin

Sample volumes from 10 to $50 \mathrm{~mL}$ containing up to $200 \mu \mathrm{g}$ of each cation were transferred to plastic vessels. It was added $10 \mathrm{~mL}$ of $\mathrm{pH} 9.0$ ammonium buffer solution and $0.5 \mathrm{~g}$ of the solid phase. The vessel was closed and kept under mechanical stirring for $5 \mathrm{~min}$. The mixture was filtered through a filter paper and the liquid phase was discharged. Solid material retained onto filter paper was washed with $5 \mathrm{~mL}$ of $3 \mathrm{~mol} \mathrm{~L}^{-1}$ nitric acid. Metals ions extracted were then directly determined by FAAS. The same procedure was applied to blanks. An analytical curve prepared in $3 \mathrm{~mol} \mathrm{~L}^{-1}$ nitric acid was used in order to avoid matrix effects.

Recommended procedure for separation and preconcentration - Dowex-ARS resin

Sample volumes from 50 to $200 \mathrm{~mL}$ containing up to $50 \mu \mathrm{g}$ of each cation were transferred to plastic vessels. It was added $10 \mathrm{~mL}$ of $\mathrm{pH} 8.1$ ammonium buffer solution and $0.75 \mathrm{~g}$ of the solid phase. The vessel was closed and kept under mechanical stirring for $90 \mathrm{~min}$. The mixture was filtered through a filter paper and the liquid phase was discharged. Solid material retained onto filter paper was washed with $20 \mathrm{~mL}$ of $2 \mathrm{~mol} \mathrm{~L}^{-1}$ nitric acid. Metals ions extracted were then directly determined by FAAS. The same procedure was applied to blanks. An analytical curve prepared in $2 \mathrm{~mol} \mathrm{~L}^{-1}$ nitric acid was used in order to avoid matrix effects.

\section{Results and Discussion}

In order to obtain quantitative recoveries of $\mathrm{Mn}, \mathrm{Cu}$, and $\mathrm{Zn}$ on XAD 7-ARS and Dowex-ARS resins the separation and preconcentration procedures were optimized using an univariate approach for various experimental parameters such as characterization of solid phases, $\mathrm{pH}$, stirring time, sample volume, amounts of solid phase, sorption capacity, and cations desorption from solid phase and concomitants effect.

Characterization of solid phases - IR spectra Amberlite XAD-7 and Dowex 1X8-50 loaded with Alizarin Red-S

The chelating resins were characterized employing Fourier transform infrared spectrometry (FTIR). The characteristic IR bands (in $\mathrm{cm}^{-1}$ ) for XAD 7-ARS resin were: 3503 and 1444 (OH vibrations); 1656 (1,4-quinone stretching); 1348 (>S=O stretching); and 1275 (>C-O stretching). For ARS loaded Dowex 1X8-50, the IR spectrum was analogous but lower intensities and deformation bands due to impregnating process agent chelating-resin (ion exchange) were observed. Because of the absence of ion-exchange sites in Amberlite XAD-7 structure, this sorbent is more able to retain molecule of ARS. The occurrence of five bands further supports the loading of the chelating agent on the resins.

\section{Effect of $\mathrm{pH}$ on $\mathrm{Mn}, \mathrm{Cu}$, and $\mathrm{Zn}$ sorption}

Effect of $\mathrm{pH}$ on the chelating efficiency of XAD 7-ARS and Dowex-ARS for manganese, copper, and zinc was tested by batch experiments using $25 \mathrm{~mL}$ of aqueous solutions containing $25 \mu \mathrm{g}$ of metal ions and $1.0 \mathrm{~g}$ of the resins. The $\mathrm{pH}$ of the solutions was varied and adjusted in the range 3.0-10.0. Recoveries (\%) of $\mathrm{Cu}(\mathrm{II}), \mathrm{Mn}(\mathrm{II})$, and $\mathrm{Zn}(\mathrm{II})$ as a function of $\mathrm{pH}$ for the XAD 7-ARS and DowexARS resins are shown in Figures 1 and 2, respectively. The results for XAD 7-ARS resin demonstrated that maximum extraction (over $95 \%$ for all cations) is achieved for $\mathrm{pH}$ ranging from 8.5 to 10.0 . For the Dowex-ARS resin, maxima recoveries for $\mathrm{Mn}$ and $\mathrm{Cu}$ were 8.1 to 9.0, respectively, and for $\mathrm{Zn}$ was $\mathrm{pH}$ 8.1. In subsequent studies, the $\mathrm{pH}$ was maintained at 9.0 and 8.1, using an ammonium 
buffer, for XAD 7-ARS and Dowex-ARS resins, respectively.

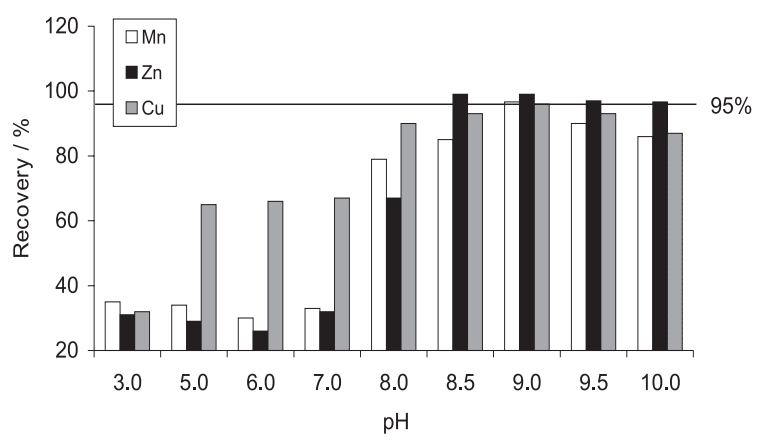

Figure 1. Effect of $\mathrm{pH}$ on cations extraction by XAD 7-ARS resin. Mass of each cation: $50.0 \mu \mathrm{g}$. Sample volume: $25 \mathrm{~mL}$. Phase solid mass: $1 \mathrm{~g}$ with $0.5 \%(\mathrm{~m} / \mathrm{m})$ ARS. Shaking time: $30 \mathrm{~min}$. Back extraction: 2 extractions with $25.0 \mathrm{~mL} \mathrm{HNO}_{3} 6 \mathrm{~mol} \mathrm{~L}^{-1}$

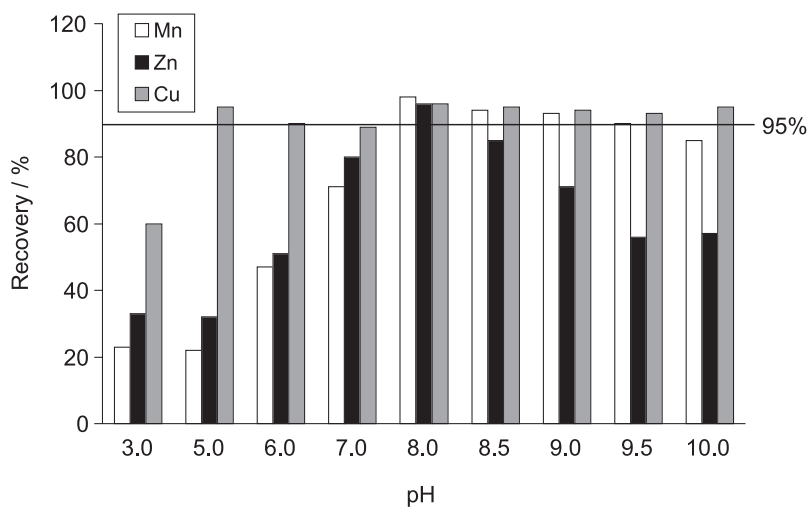

Figure 2. Effect of $\mathrm{pH}$ on cations extraction by Dowex-ARS resin. Mass of each cation: $50.0 \mu \mathrm{g}$. Sample volume: $25 \mathrm{~mL}$. Phase solid mass: $1 \mathrm{~g}$ with $0.5 \%(\mathrm{~m} / \mathrm{m})$ ARS. Shaking time: $30 \mathrm{~min}$. Back extraction: 2 extractions with $25.0 \mathrm{~mL} \mathrm{HNO}_{3} 6 \mathrm{~mol} \mathrm{~L}^{-1}$

\section{Effect of shaking time}

For determining the effect of the reaction time on the rate of loading of $\mathrm{Cu}(\mathrm{II}), \mathrm{Mn}(\mathrm{II})$, and $\mathrm{Zn}$ (II) on the solid phases, the chelating resins beads $(1.0 \mathrm{~g})$ were stirred with $50 \mathrm{~mL}$ de solution containing $10 \mathrm{~mL}$ ammonium buffer and all the metal ions ( $50 \mu \mathrm{g}$ of each) at room temperature from 1 to $60 \mathrm{~min}$ for XAD 7-ARS resin and from 1 to 120 min for Dowex-ARS resin. Results demonstrated that for the XAD 7-ARS system, the shaking time required for quantitative sorption was $5 \mathrm{~min}$. The Dowex-ARS resin showed a behavior different, with maximum recoveries obtained only at time $\geq 60 \mathrm{~min}$ for $\mathrm{Mn}$ and $90 \mathrm{~min}$ for $\mathrm{Cu}$ and $\mathrm{Zn}$. However, $90 \mathrm{~min}$ was preferred to further experiments for obtaining the simultaneous separation and preconcentration of the metallic ions. The large difference in the shaking time between the two systems can be explained by the impregnation process of the Dowex 1 X8-
50 with ARS, because in the value of $\mathrm{pH}$ established it can occurs stereo hindrance between resonance of the aromatic ring and oxygen atoms of the ARS, making the complexation of metallic ions difficult. ${ }^{23}$ This was not observed with XAD 7-ARS resin because the impregnation process occurs by physical adsorption.

\section{Choice of eluent}

Solutions of sulfuric, nitric, and hydrochloric acids in different concentrations $(0.5 ; 1.0 ; 2.0 ; 3.0 ; 5.0$; and $\left.7.0 \mathrm{~mol} \mathrm{~L}^{-1}\right)$ and volumes (1-50 mL) were tested to desorb $\mathrm{Mn}, \mathrm{Cu}$, and $\mathrm{Zn}$ from solids phases. It was essential to select an eluent that could also be used for FAAS measurements without problems. The best results for quantitative recoveries of the metallic ions were obtained using nitric acid as eluent. It was found that $5 \mathrm{~mL}$ of $3.0 \mathrm{~mol} \mathrm{~L}^{-1} \mathrm{HNO}_{3}$ and $20 \mathrm{~mL}$ of $2.0 \mathrm{~mol} \mathrm{~L}^{-1} \mathrm{HNO}_{3}$ were sufficient for quantitative ( $>95 \%$ ) elution of $\mathrm{Mn}, \mathrm{Cu}$, and $\mathrm{Zn}$, in a single step, in the XAD 7-ARS and Dowex-ARS resins, respectively.

\section{Influence of volume of aqueous phase}

Since the volume of solid phase was small compared to the aqueous phase, it was important to study the effect of the latter on the separation and preconcentration of $\mathrm{Mn}(\mathrm{II}), \mathrm{Cu}$ (II), and $\mathrm{Zn}$ (II). The volume of the aqueous phase was varied from 10 to $1000 \mathrm{~mL}$, and the retention was found to be quantitative when the volume of the aqueous phase did not exceed $100 \mathrm{~mL}$, for determination of $\mathrm{Zn}$ and $\mathrm{Cu}$ using Dowex-ARS resin; and $50 \mathrm{~mL}$ for determination of $\mathrm{Mn}, \mathrm{Cu}$, and $\mathrm{Zn}$ using XAD 7-ARS resin.

\section{Effect of mass of solid phase}

The mass of solid phases were varied from 0.1 to $1.0 \mathrm{~g}$ under optimum conditions. Results demonstrated that 0.50 $\mathrm{g}$ and $0.75 \mathrm{~g}$, respectively, of XAD 7-ARS and DowexARS resins, were sufficient for quantitative retention of $\mathrm{Mn}(\mathrm{II}), \mathrm{Cu}(\mathrm{II})$, and $\mathrm{Zn}(\mathrm{II})$.

\section{Sorption capacity of the solid phases}

Solid phase sorption capacity was also assessed with a multielemental solution. The sorption capacity of the solid phases, XAD 7-ARS and Dowex-ARS resins, for $\mathrm{Mn}, \mathrm{Cu}$, and $\mathrm{Zn}$ was determined using parameters optimized and a set of solutions containing different amounts of metallic ions in the range of 5-1000 $\mu \mathrm{g}$. Results demonstrated that $0.50 \mathrm{~g}$ of XAD 7-ARS resin had a capacity to retain up to 
$500 \mu \mathrm{g}$ of $\mathrm{Mn}(\mathrm{II})$, and up to $200 \mu \mathrm{g}$ of $\mathrm{Cu}(\mathrm{II})$ and $\mathrm{Zn}$ (II). It was observed that $0.75 \mathrm{~g}$ of solid phase Dowex-ARS, was efficient to retain up to $50 \mu \mathrm{g}$ of each one of the cations.

\section{Effect of electrolytes}

The effect of $\mathrm{NaCl}, \mathrm{KCl}, \mathrm{BaCl}_{2}, \mathrm{CaCl}_{2}, \mathrm{Na}_{2} \mathrm{SO}_{4}, \mathrm{MgCl}_{2}$ and $\mathrm{Na}_{3} \mathrm{PO}_{4}$ on the sorption of $\mathrm{Mn}$ (II), $\mathrm{Cu}$ (II), and $\mathrm{Zn}$ (II) in the proposed systems was also studied. A set of solutions containing varying amount of electrolyte $(0.5 ; 1.0 ; 3.0$; and $5.0 \% \mathrm{~m} / \mathrm{v}$ ) was taken and the recommended procedures applied. Various amounts of matrix ions were added to a solution containing fixed amounts of analytes $(50 \mathrm{mg}$ of $\mathrm{Mn}(\mathrm{II}), \mathrm{Cu}(\mathrm{II})$, and $\mathrm{Zn}$ ). Phosphate interferes in the sorption of $\mathrm{Zn}$ (II) in all proportions, due to precipitation losses of $\mathrm{Zn}$; the other electrolytes did not interfere up to $5 \% \mathrm{~m} / \mathrm{v}$. For $\mathrm{Cu}(\mathrm{II})$, the presence of $\mathrm{NaCl}, \mathrm{Na}_{2} \mathrm{SO}_{4}, \mathrm{Na}_{3} \mathrm{PO}_{4}$, and $\mathrm{KCl}$ did not interfere in the determination of the metal until a concentration of $5.0 \% \mathrm{~m} / \mathrm{v} . \mathrm{Mg}^{2+}, \mathrm{Ba}^{2+}$ and $\mathrm{Ca}^{2+}$ interfered in all proportions. For $\mathrm{Mn}(\mathrm{II}), \mathrm{Na}_{2} \mathrm{SO}_{4}, \mathrm{Mg}^{2+}$ and $\mathrm{Ba}^{2+}$ were tolerated until a concentration of $5.0 \% \mathrm{~m} / \mathrm{v}, 0.5 \% \mathrm{~m} / \mathrm{v}$ and $3.0 \% \mathrm{~m} / \mathrm{v}$, respectively, and $\mathrm{Ca}^{2+}$ interfere considerably.

\section{Solid phases stability}

Adsorption and desorption were repeated on the same solid phases and adsorptive capacity was estimated after each cycle of operation. The capacity of the XAD 7-ARS resin was also found to be practically constant (within $3-4 \%$ ) after repeated use more than six times. For the Dowex-ARS resin the results indicated that this could be used only one time.

\section{Analytical figures of merit and application}

The accurate determination of $\mathrm{Mn}$ (II), $\mathrm{Cu}$ (II), and $\mathrm{Zn}$ (II) at low concentration levels in seawater and physiological solutions after separation and preconcentration requires low and reproducible blanks. Absolute blanks, based on the analysis of separate concentrates from different volumes of ultra pure water were submitted to the separation and preconcentration procedures. The characteristic data for the performance of the separation and preconcentration systems are summarized in Table 2. The detection and quantification limit (LOD and LOQ) for $\mathrm{Mn}, \mathrm{Cu}$ and $\mathrm{Zn}$ were determined employing the procedures to blank solutions (nitric acid in appropriate concentration). The limit of detection (3s/slope of 30 measurements of blank, where $s$ is the standard deviation of blank) and the limit of quantification (10s/slope of 30 measurements of blank) were studied. The results of the LD and LQ for the XAD 7-ARS and Dowex-ARS resins, are presented in Table 2. The precision of the procedure was determined by running 10 replicate samples, each one containing $250 \mu \mathrm{g} \mathrm{L}^{-1}$ of each element and the relative standard deviations were $0.2 \%(\mathrm{Cu}), 0.4 \%(\mathrm{Mn})$, and $0.4 \%(\mathrm{Zn})$, to XAD 7-ARS e $0.3 \%(\mathrm{Cu}), 0.5 \%(\mathrm{Mn})$, and $0.3 \%(\mathrm{Zn})$, to Dowex-ARS.

The applicability of two resins was tested for seawater and physiological solutions samples. The recommended procedures were investigated by addition of $5.0 \mu \mathrm{g}$ of $\mathrm{Mn}$, $\mathrm{Cu}$, and $\mathrm{Zn}$ to seawater, from Salvador city, Bahia-Brazil, and physiological solutions samples carried out followed by analysis with the developed methods. Results are presented in Tables 3 and 4. Application of a t-test (at the 95\% confidence level) shows no significant difference between the added recovered contents using both experimental procedures. Recovery values were always higher than $95 \%$, confirming the accuracy of the procedure and the absence of matrix effects. Manganese, $\mathrm{Cu}$, and $\mathrm{Zn}$ contents determined in seawater are lower than the allowed values (CONAMA ${ }^{24}$ ) which establishes, in the 1986 Resolution, the maximum values of the substances potentially harmful to the man in saline waters. For Mn, $\mathrm{Cu}$, and $\mathrm{Zn}$, the maximum values are $0.10,0.05$, and $0.17 \mu \mathrm{g} \mathrm{mL}^{-1}$, respectively.

Table 2. Comparison of optimized parameters for the two systems studied

\begin{tabular}{|c|c|c|}
\hline Parameters & Dowex-ARS & XAD 7-ARS \\
\hline $\mathrm{pH}$ value & 8.1 & 9.0 \\
\hline $\mathrm{HNO}_{3}\left(\mathrm{~mol} \mathrm{~L}^{-1}\right)$ for elution & 2.0 & 3.0 \\
\hline $\mathrm{HNO}_{3}(\mathrm{~mL})$ for elution & 20.0 & 5.0 \\
\hline Loading time (min) & 90 & 5 \\
\hline Quantity of solid phase (g) & 0.75 & 0.50 \\
\hline Adsorptive capacity $\left(\mathrm{mg} \mathrm{g}^{-1}\right)$ & 50 & $\mathrm{Mn}: 500 ; \mathrm{Zn}$ and $\mathrm{Cu}: 200$ \\
\hline Preconcentration factor & $\mathrm{Zn}$ and $\mathrm{Cu}: 5$ & $\mathrm{Zn}: 50 ; \mathrm{Mn}$ and $\mathrm{Cu}: 10$ \\
\hline Limit of detection $\left(\mu \mathrm{g} \mathrm{L}^{-1}\right)$ & $\mathrm{Mn}: 25 ; \mathrm{Zn} \mathrm{23;} \mathrm{and} \mathrm{Cu}: 9$ & Mn: 32; Zn 29; and $\mathrm{Cu}: 10$ \\
\hline Limit of quantification $\left(\mu \mathrm{g} \mathrm{L}^{-1}\right)$ & Mn: 82; Zn 76; Cu:29 & Mn: 105; Zn 98; Cu: 35 \\
\hline
\end{tabular}


Table 3. Determination of $\mathrm{Mn}, \mathrm{Cu}$, and $\mathrm{Zn}$ in saline samples using XAD 7-ARS resin. Mean and standard deviations $(\mathrm{n}=3)$

\begin{tabular}{|c|c|c|c|}
\hline Samples & $\mathbf{C u}\left(\mu \mathrm{g} \mathrm{mL}^{-1}\right)$ & $\mathbf{Z n}\left(\mu \mathrm{g} \mathrm{mL}^{-1}\right)$ & $\mathbf{M n}\left(\mu \mathrm{g} \mathrm{mL}^{-1}\right)$ \\
\hline Physiological solution 1 & $\begin{array}{c}0.022 \pm 0.001 \\
(97 \%)^{\mathrm{a}}\end{array}$ & $\begin{array}{c}0.028 \pm 0.002 \\
(96 \%)^{\mathrm{a}}\end{array}$ & $\begin{array}{c}0.026 \pm 0.001 \\
(97 \%)^{\mathrm{a}}\end{array}$ \\
\hline Physiological solution 2 & $\begin{array}{c}0.019 \pm 0.001 \\
(97 \%)^{\mathrm{a}}\end{array}$ & $\begin{array}{c}0.021 \pm 0.004 \\
(95 \%)^{\mathrm{a}}\end{array}$ & $\begin{array}{c}0.024 \pm 0.002 \\
(96 \%)^{\mathrm{a}}\end{array}$ \\
\hline Ondina seawater & $\begin{array}{c}0.060 \pm 0.001 \\
(97 \%)^{\mathrm{a}}\end{array}$ & $\begin{array}{c}0.110 \pm 0.004 \\
(97 \%)^{\mathrm{a}}\end{array}$ & $\begin{array}{c}0.123 \pm 0.003 \\
(98 \%)^{\mathrm{a}}\end{array}$ \\
\hline Rio Vermelho seawater & $\begin{array}{c}0.053 \pm 0.001 \\
(97 \%)^{\mathrm{a}}\end{array}$ & $\begin{array}{c}0.092 \pm 0.003 \\
(99 \%)^{\mathrm{a}}\end{array}$ & $\begin{array}{c}0.117 \pm 0.001 \\
(96 \%)^{\mathrm{a}}\end{array}$ \\
\hline Porto da Barra seawater & $\begin{array}{c}0.061 \pm 0.001 \\
(95 \%)^{\mathrm{a}}\end{array}$ & $\begin{array}{c}0.112 \pm 0.002 \\
(99 \%)^{\mathrm{a}}\end{array}$ & $\begin{array}{c}0.115 \pm 0.002 \\
(98 \%)^{\mathrm{a}}\end{array}$ \\
\hline
\end{tabular}

a\% Recovery (spiking: $5.0 \mathrm{mg}$ of $\mathrm{Mn}, \mathrm{Cu}$, and $\mathrm{Zn}$ ).

Table 4. Determination of $\mathrm{Mn}, \mathrm{Cu}$, and $\mathrm{Zn}$ in saline samples using Dowex-ARS resin. Mean and standard deviations $(\mathrm{n}=3)$

\begin{tabular}{|c|c|c|c|}
\hline Samples & $\mathbf{C u}\left(\mu \mathrm{g} \mathrm{mL}^{-1}\right)$ & $\mathbf{Z n}\left(\mu \mathrm{g} \mathrm{mL}^{-1}\right)$ & $\mathbf{M n}\left(\mu \mathrm{g} \mathrm{mL}^{-1}\right)$ \\
\hline Physiological solution 1 & $\begin{array}{c}0.020 \pm 0.002 \\
(98 \%)^{\mathrm{a}}\end{array}$ & $\begin{array}{c}0.035 \pm 0.004 \\
(99 \%)^{\mathrm{a}}\end{array}$ & $\begin{array}{c}0.026 \pm 0.003 \\
(95 \%)^{\mathrm{a}}\end{array}$ \\
\hline Physiological solution 2 & $\begin{array}{c}0.018 \pm 0.001 \\
(96 \%)^{\mathrm{a}}\end{array}$ & $\begin{array}{c}0.034 \pm 0.002 \\
(99 \%)^{\mathrm{a}}\end{array}$ & $\begin{array}{c}0.022 \pm 0.002 \\
(95 \%)^{\mathrm{a}}\end{array}$ \\
\hline Ondina seawater & $\begin{array}{c}0.059 \pm 0.002 \\
(95 \%)^{\mathrm{a}}\end{array}$ & $\begin{array}{c}0.095 \pm 0.003 \\
(101 \%)^{\mathrm{a}}\end{array}$ & $\begin{array}{c}0.118 \pm 0.002 \\
(95 \%)^{\mathrm{a}}\end{array}$ \\
\hline Rio Vermelho seawater & $\begin{array}{c}0.061 \pm 0.001 \\
(96 \%)^{\mathrm{a}}\end{array}$ & $\begin{array}{c}0.085 \pm 0.004 \\
(100 \%)^{\mathrm{a}}\end{array}$ & $\begin{array}{c}0.118 \pm 0.002 \\
(95 \%)^{\mathrm{a}}\end{array}$ \\
\hline Porto da Barra seawater & $\begin{array}{c}0.051 \pm 0.001 \\
(95 \%)^{\mathrm{a}}\end{array}$ & $\begin{array}{c}0.108 \pm 0.003 \\
(96 \%)^{\mathrm{a}}\end{array}$ & $\begin{array}{c}0.112 \pm 0.001 \\
(95 \%)^{\mathrm{a}}\end{array}$ \\
\hline
\end{tabular}

a\% Recovery (spiking: $5.0 \mu \mathrm{g}$ of $\mathrm{Mn}, \mathrm{Cu}$, and $\mathrm{Zn}$ ).

\section{Conclusions}

The present paper is focused on the analytical problem of trace analysis of saline matrices by FAAS, and the fact that $\mathrm{Mn}, \mathrm{Cu}$, and $\mathrm{Zn}$ are trace constituents, in clinical and environmental samples. Two procedures using chelating resins obtained by modification of nonionic polymer sorbent Amberlite XAD-7 and anion exchanger Dowex 1X8-50 with Alizarin Red S are proposed for separation and preconcentration of $\mathrm{Mn}, \mathrm{Cu}$, and $\mathrm{Zn}$ from saline matrices. The procedures developed are simple and efficient. The system XAD 7-ARS presented some advantages due to rapid kinetic, low consumption of reagents and eluent, good stability and a good enrichment factor (up to 50x for $\mathrm{Zn}$ ). The sorption capacity and preconcentration factor of alizarin red $\mathrm{S}$ loaded in Amberlite XAD-7 are higher than the alizarin red S loaded in Dowex 1X8-50. Furthermore, the elution step does not involve the use of organic solvents as others procedures. The addition recovery experiments showed that the proposed procedures had proper accuracy. The proposed method is simple and suitable for the separation and determination of $\mathrm{Mn}, \mathrm{Cu}$, and $\mathrm{Zn}$ in saline samples.

\section{Acknowledgements}

The authors are grateful to the CNPq (Conselho Nacional de Desenvolvimento Científico e Tecnológico), FINEP (Financiadora de Estudos e Projetos), CAPES (Coordenação de Aperfeiçoamento de Pessoal de Nível Superior) and SEPLANTEC/CADCT by financial support and fellowships (A. de F.S.J., H.V.J. and N.M.S.S.). M.G.A.K. and A.C.S.C also would like to thank CNPq by research scholarships provided and Dra. Cristina Coelho for reading of the English manuscript.

\section{References}

1. Soylak, M.; Elci, L.; Dogan, M.; Anal. Lett. 1993, 26, 1997.

2. Herruzo, F.H.; Garcia, I.N.; Coronel, F.J.M.; Jimenez, J.J.R.; Afinidad 1987, XLVI, 409.

3. Sargentelli, V.; Mauro, A .E.; Massabi, A .C.; Quim. Nova. 1996, 19, 290.

4. Prasad, A. S.; Oberleas, D.; Trace Elements in Human Health and Disease, Academic Press: New York, 1976, vol. 1.

5. Tsalev, D.L.; Atomic Absorption Spectrometry in Occupational and Environmental Health Practice, CRC Press: Boca Raton, 1984, vol. II. 
6. Tanaka, S.; Occupational Medicine, Mosby - Year Book: Saint Louis, 1994.

7. Galvão, L.A.C.; Corey, G.; Manganeso-Serie Vigilancia, Centro Panamericano de Ecologia Humana y Salud: México, 1987.

8. Welz, B.; Sperling, M.; Atomic Absorption Spectrometry; $3^{\text {rd }}$ ed., VCH: Weinheim, Germany, 1999.

9. Marhol, M.; Ion Exchangers in Analytical Chemistry their Proprieties and Use in Inorganic Chemistry, Elsevier: New York, 1982.

10. Marina, M. L.; Gonzalez, V.; Rodríguez, A. R.; Microchem. J. 1986, 33, 275.

11. Zhang, M.; Florence, T. M.; Anal. Chim. Acta 1987, 197, 137.

12. Ferreira, S.L.C.; Ferreira, J.R.; Dantas, A.F.; Lemos, V.A.; Araújo, N.M.L.; Costa, A.C.S.; Talanta 2000, 50, 1253.

13. Ferreira, S.L.C.; Brito, C.F.; Anal. Sci. 1999, 15, 189.

14. Soylak, M.; Sahin, U.; Elci, L.; Anal. Chim. Acta 1996, 322, 111.

15. Soylak, M.; Dogan, M.; Trace Elem. Eletroly. 1996, 13, 130.

16. Soylak, M.; Divrikli, U.; Dogan, M. J.; Trace Microprobe T. 1997, 15, 197.
17. Tewari, P. K.; Singh, A K.; Fresenius'. J. Anal. Chem. 2000, 367, 562.

18. Ferreira, S.L.C.; Brito, C.F.; Dantas, A.F.; Araújo, N.M.L.; Costa, A.C.S.; Talanta 1999, 48, 1173.

19. Singh, A. K.; Dhingra, S.K.; Analyst 1992, 117, 889.

20. Tewari, P. K.; Singh, A. K. Talanta 2002, 56, 735.

21. Saxena, R.; Singh, A K.; Sambi, S. S.; Anal.Chim. Acta 1994, 295, 199.

22. Nagahiro, T.; Wang, G. F.; Satake, M.; Microchem. J. 1995, $52,247$.

23. Ueno, K.; Imamura, T.; Cheng, K.L.; Handbook of Organic Analytical Reagents; CRC Press: Boca Raton, 1992.

24. CONAMA; Conselho Nacional do Meio Ambiente, Resolution Number 20, Brazil, 1986. http://www.mma.gov.br/port/ conama, accessed in September 2003.

Received: March 10, 2003 Published on the web: February 27, 2004 